\title{
Urbanization of visceral leishmaniasis (kala-azar) in Fortaleza, Ceará, Brazil
}

\author{
Polianna Lemos Moura Moreira Albuquerque, ${ }^{1,2}$ \\ Geraldo Bezerra da Silva Júnior, ${ }^{1,2}$ Caio César Furtado Freire, ${ }^{1}$ \\ Stephanie Bachi de Castro Oliveira, ${ }^{2}$ Daniel Medeiros Almeida, ${ }^{2}$ \\ Herivaldo Ferreira da Silva, ${ }^{3}$ Maria do Socorro Cavalcante, ${ }^{4}$ \\ and Anastácio de Queiroz Sousa ${ }^{5}$
}

Suggested citation Albuquerque PLMM, Silva Júnior GB, Freire CCF, Oliveira SBC, Almeida DM, Silva HF, et al. Urbanization of visceral leishmaniasis (kala-azar) in Fortaleza, Ceará, Brazil. Rev Panam Salud Publica. 2009; 26(4):330-3.

ABSTRACT Objectives. Visceral leishmaniasis $(V L)$ is endemic in Brazil and appears to occur in epidemic form in the state of Ceará. Few epidemiologic studies have been done on VL in this state. The aim of this study is to establish the epidemiologic pattern of VL in Fortaleza City and to show how urbanization has occurred in recent years.

Methods. Data were obtained from the State Health Department of Fortaleza, Ceara, and included all cases of VL registered in Fortaleza from January 2001 to December 2006.

Results. There were a marked increase and an elevated incidence of cases of VL in urban areas. Children and young people were the most affected group.

Conclusion. The epidemic occurrence of VL in the region must convince authorities to adopt more adequate policies of disease control.

Key words Leishmaniasis, visceral; kala-azar; epidemiology; urban zones; Brazil.

Visceral leishmaniasis (VL), also known as kala-azar, is the more severe form of leishmaniasis, with high mortality if not adequately treated. The disease

1 Hospital Geral César Cals de Oliveira, Fortaleza, Ceará, Brazil. Send correspondence and reprint requests to: Dra. Polianna Lemos Moura Moreira Albuquerque, Rua Sigefredo Pinheiro, no. 100, apto 101, Bairro de Fátima, Fortaleza, Ceará, Brazil; telephone: +55 853472 2451/+55 858887 5528; e-mail: pollylemos@yahoo.com.br, geraldobezerrajr@yahoo. com.br

2 School of Medicine, Universidade Federal do Ceará, Fortaleza, Ceará, Brazil.

3 Hospital Geral César Cals de Oliveira and Universidade Estadual do Ceará, Fortaleza, Ceará, Brazil.

4 Epidemiology Division of Hospital Geral César Cals de Oliveira, Fortaleza, Ceará, Brazil.

5 Infectious Diseases, Universidade Federal do Ceará, Fortaleza, Ceará, Brazil. is caused by protozoan parasites that belong to the genus Leishmania and is transmitted by the bite of certain species of sand fly (order Diptera, family Psychodidae, subfamily Phlebotominae). The global prevalence of VL is around 12 million people (1). The World Health Organization estimates an incidence of 500,000 cases per year. VL now has a wider geographic distribution and is being reported in previously nonendemic areas (2).

$\mathrm{VL}$ is one of the seven most neglected tropical diseases in the world (3). It is endemic in 88 countries in Africa, Asia, Europe, and Latin America. It is considered one of the most important endemic dis- eases in the world (4). Approximately $90 \%$ of cases registered in the Americas occur in Brazil. The high incidence of leishmaniasis, Chagas disease, and African trypanosomiasis suggests that they are out of control (3). The incidence and mortality of VL grow annually with a lethality around $10 \%$ (5).

The northeastern region of Brazil is responsible for $70 \%$ to $90 \%$ of cases; in recent years "urbanization" of VL has been observed, with important outbreaks documented in large Brazilian cities (6). The most affected Brazilian states are Bahia, Ceará, Piauí, and Maranhão (4).

There are three main forms of manifestations of VL: oligosymptomatic, acute, 
and chronic (classic VL). The more frequently diagnosed form is classic VL. Children $<10$ years old are the most affected age group (7), with some variation among published studies. Diagnosis of VL is based on epidemiology data and clinicolaboratory features. Definitive diagnosis is achieved by identifying the parasite in infected tissues (8). VL can also be identified with K-39, an antigen of leishmanias, if the parasite is not found. The test is noninvasive with high sensitivity ( 100\%) and specificity ( 98\%) (9). Treatment is done principally with pentavalent antimonials as suggested by the World Health Organization (8).

Few studies have been done on VL in Ceará, Brazil. This study was performed to trace the epidemiologic pattern of VL in the region and to contribute to adoption of more adequate policies of disease control.

\section{MATERIALS AND METHODS}

A cross-sectional study was done that included all cases of VL registered in Fortaleza, Ceará, Brazil, from January 2001 to December 2006. A suspected case was defined, according to the surveillance guide of the Brazilian Ministry of Health, as a subject with fever and splenomegaly from an endemic area or one with fever and splenomegaly from an area where VL transmission does not occur after all other differential diagnoses have been ruled out.

Cases were classified according to recommendations of the Ministry of Health based on clinicolaboratory and epidemiologic features. Clinicolaboratory criteria
FIGURE 1. Confirmed cases of visceral leishmaniasis, Fortaleza, Ceará, Brazil, January 2001 to December 2006

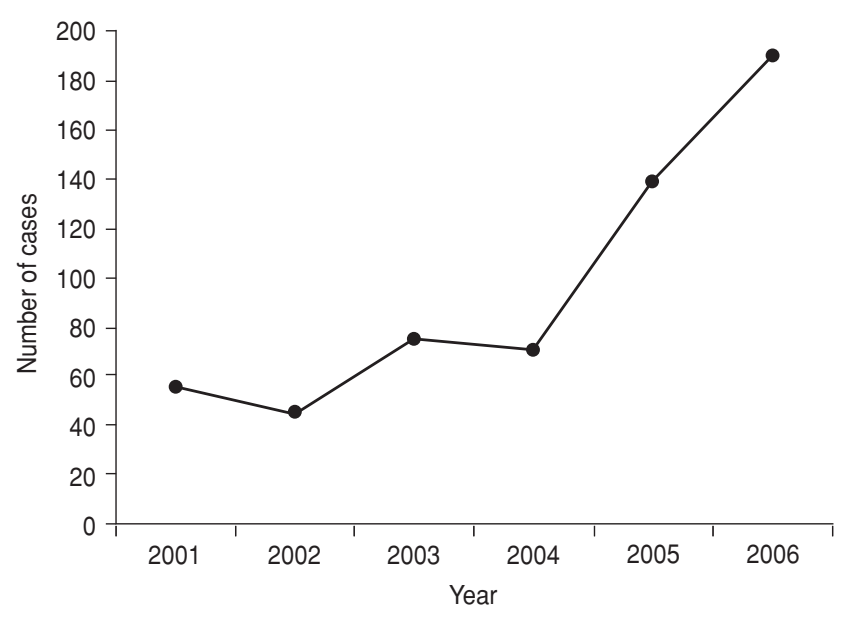

were defined as identification of the parasite in infected tissue, a positive culture, or an immunofluorescence test with a titer higher than 1:80 and exclusion of other differential diagnoses. A clinicoepidemiologic criterion was defined as a case from an endemic area with clinical features suggestive of VL, without laboratory confirmation, but with good response to medical therapy.

All data were obtained from the State Health Department of Fortaleza, Ceará, through the compulsory diseases notification form. The analyzed variables were gender, age, city of precedence, place of residence, treatment, final case classification, and outcome. Statistical analysis was done through the program Epi-Info 6.04 (Centers for Disease Control and Prevention, Atlanta, Georgia, United States of America).

\section{RESULTS}

During the study period, 1379 cases of VL were registered in Fortaleza, and 990 of them were confirmed. A significant increase in the number of cases has been observed in recent years (Figure 1).

Among the registered cases, 576 (58.2\%) were from the capital city, Fortaleza, and the remainder were from the countryside. When the incidence of VL in the metropolitan region of Fortaleza is considered, the percentage of cases rises to $73.1 \%$. A significant migration of patients to the capital was observed, where notification is done and treatment is provided.

In the city of Fortaleza, VL occurred mainly in children between 4 and 5 years old and in young people aged 25 and 26 years, reflecting a bimodal pattern of incidence (Figure 2). Most cases registered

\section{FIGURE 2. Age distribution of confirmed cases of visceral leishmaniasis, Fortaleza, Ceará, Brazil, January 2001 to December 2006}

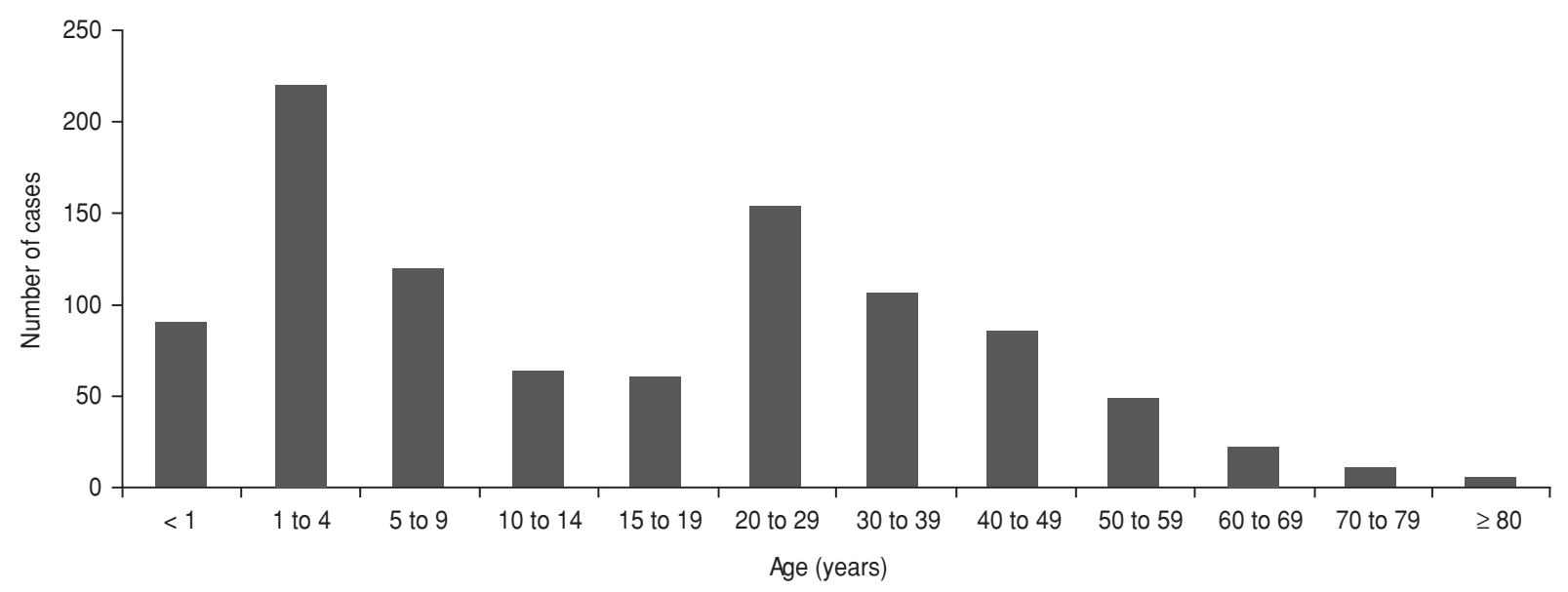


FIGURE 3. Gender distribution of confirmed cases of visceral leishmaniasis, Fortaleza, Ceará, Brazil, January 2001 to December 2006

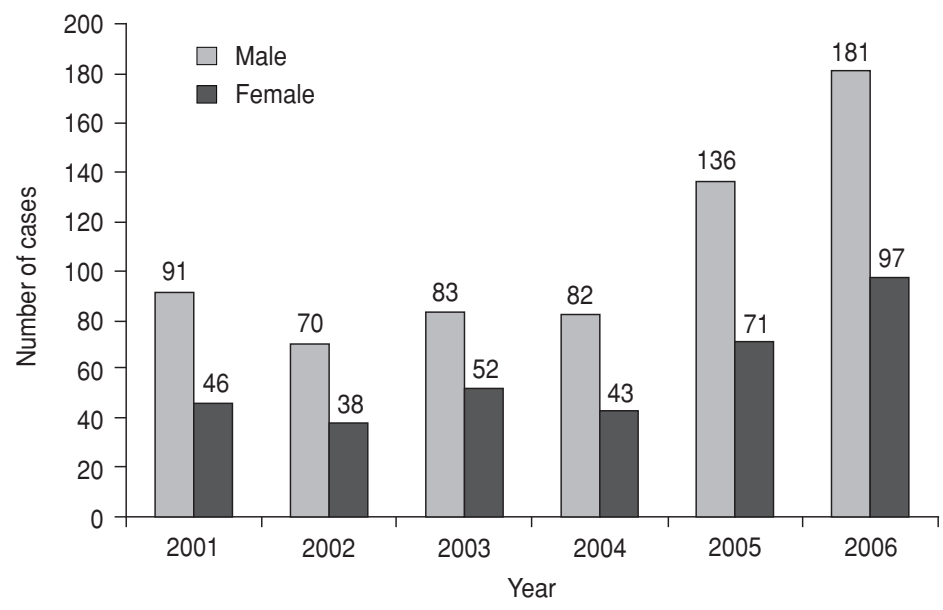

FIGURE 4. Confirmed cases of visceral leishmaniasis by living area, Fortaleza, Ceará, Brazil, January 2001 to December 2006

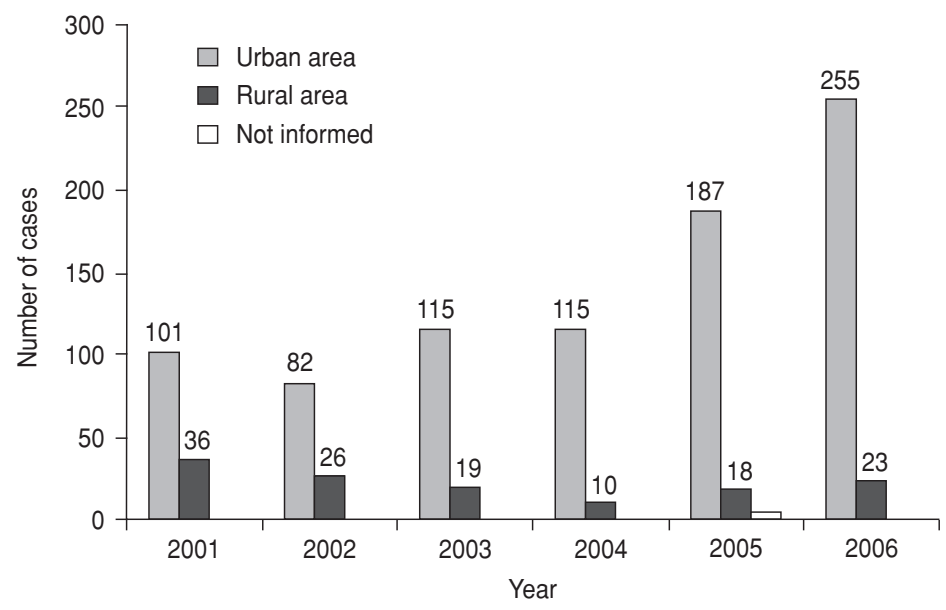

in Fortaleza were male (65\%), as shown in Figure 3 ( $p<0.001$; Fisher exact test).

The geographic distribution of VL showed a predominance in urban areas (86.4\%; $p<0.001$; Fisher exact test). Throughout the period of analysis, there was no significant variation in the incidence of VL in rural areas. However, the incidence in urban areas showed a huge increase, around $121 \%$ between 2004 and 2006 (Figure 4).

Analysis of the educational level was prejudiced by a lack of complete notification forms. Around $41.2 \%$ of 238 reported cases had studied 4 to 7 years. Analysis of other variables was not possible because of a lack of information. Twenty-three reports of an association between VL and HIV infection and 11 cases of associated tuberculosis were found.

Frequent clinical manifestations were fever $(86.2 \%)$, splenomegaly $(67.5 \%)$, he- patomegaly (62.6\%), and malaise (47.7\%). Diagnosis was done mainly through bone marrow aspirate $(55.5 \%)$. There were 140 cases in which the exam was not performed, and the remainder did not have information about the diagnosis procedure. Indirect immunofluorescence was positive in $20 \%$ of cases, and enzyme-linked immunosorbent assay was positive in only $4.7 \%$ of cases.

Treatment was done mainly with pentavalent antimonials (77\% of cases). Of the 990 confirmed cases, $19(1.9 \%)$ were not treated. Most patients were cured $(92.2 \%)$; case fatality rate was $5.4 \%$.

\section{DISCUSSION}

VL is an endemic disease in Brazil with increasing incidence $(5,10,11)$. The most important aspects of VL-including clinical features, diagnosis, and treatment-are well known, but adequate control of the disease has still not been achieved (5), which demonstrates the need to discuss the problem and to adopt more rigid methods of disease control.

In 2005 in Brazil, 3727 cases of VL were registered. The state of Ceará had the sixth highest number of cases $(n=400)$. States with more cases were Minas Gerais, Piauí, Bahia, Pará, and Maranhão (12). In 2006, 4526 cases were registered in Brazil; the state of Ceará had the highest number of cases, with $20 \%$ of total cases in the country. The second highest number of cases was found in the state of Pará, with 599 cases (12).

The significance of the region in the number of VL cases has increased. According to official data of the Brazilian government, 1636 cases of VL were reported in Ceará between 2001 and 2006. Fortaleza represents around $60 \%$ of VL notifications, which demonstrates that this city-the fifth largest in Brazil-is responsible for most notifications between 2001 and 2006. Studies in other areas of Brazil show that the geographic distribution of VL changed from being a typical "rural disease" (5). This study reinforces the notion that urbanization of VL is increasing. The migration of patients to Fortaleza in order to receive a correct diagnosis and treatment is partly responsible for increased notifications in the capital. The increasing number of cases of VL is also partly due to deforestation. Other studies have shown that extensive deforestation increases the risk of human-vector contact $(13,14)$.

The predominance of VL in pediatric patients has been documented in the medical literature (7). In this study, the predominant age group consisted of children less than 10 years old. Male gender and urban inhabitants were the groups predominantly affected, similar to results of other studies in Brazil (15).

Urbanization of VL is well documented in the literature $(2,5)$. The disorganized increase in population around large cities favors the occurrence of poor living conditions with poor sanitation. This fact favors the transmission of VL, mainly in association with infected domestic animals (16).

Specific treatment for VL is effective. The first line of therapy consists of pentavalent antimonial drugs, which were administered for approximately $80 \%$ of cases analyzed here. The length of treat- 
ment varies according to region and potential occurrence of resistance (17). In this study, more than $90 \%$ of patients were cured, and $5.4 \%$ died. The mortality rate registered in Brazil is around 6\%,

. Desjeux P. The increase in risk factors for leishmaniasis worldwide. Trans R Soc Trop Med Hyg. 2001;95:239-43.

2. Urbanization: an increasing risk factor for leishmaniasis. Wkly Epidemiol Rec. 2002;44 (1):365-70.

3. Holtez PJ, Molyneux DH, Sachs SE, Fenwick A, Kumerasan J, Sacks JD, et al. Control of neglected tropical diseases. N Engl J Med. 2007; 357:1018-27.

4. Ministério da Saúde. Secretaria de Vigilância em Saúde. Departamento de Vigilância Epidemiológica. Manual de vigilância e controle da leishmaniose visceral. Brasília: Ministério da Saúde; 2003. Available from: http:// dtr2001.saude.gov.br/editora/produtos/ livros/pdf/03_1193_M.pdf. Accessed 12 December 2007.

5. Torres FT, Brandão Filho SP. Visceral leishmaniasis in Brazil: revisiting paradigms of epidemiology and control. Rev Inst Med Trop Sao Paulo. 2006;48(3):151-6.

6. Pearson RD, Souza AQ. Leishmania species: visceral (kala-azar), cutaneous and mucosal leishmaniasis. In: Mandell GL, Douglas RG, Bennett JB, eds. Principles and practice of in- which is similar to that observed in the region (12).

In summary, $\mathrm{VL}$ is an endemic disease that is reaching epidemic levels in northeastern Brazil. Urbanization of VL ac- companies the growth of miserable living conditions of people in those areas. Mortality remains significant. More aggressive disease control measures must be adopted.

\section{REFERENCES}

fectious diseases. 3rd ed. New York: Churchill Livingstone; 1990. Pp. 2066-77.

7. Rey LC, Martins CV, Ribeiro HB, Lima AAM. American visceral leishmaniasis (kala-azar) in hospitalized children from an endemic area. J Pediatr (Rio J). 2005;81(1):73-8.

8. Pastorino AC, Jacob CMA, Oselka GW, Sampaio MMSC. Visceral leishmaniasis: clinical and laboratorial aspects. J Pediatr (Rio J). 2002;78(2):120-7.

9. Goswani RP, Bairagi B, Kundu PK. K-39 striptest, easy, reliable and cost-effective field diagnosis for visceral leishmaniasis in India. J Assoc Physicians India. 2003;51:759-61.

10. Mendes WS, Silva AAM, Trovão JR, Silva AR, Costa LML. Space expansion of the American visceral leishmaniasis in São Luis, Maranhão, Brazil. Rev Soc Bras Med Trop. 2002;35(3): 227-31.

11. Costa $\mathrm{CHN}$, Pereira HF, Araújo MV. Visceral leishmaniasis epidemic in Piaui State, Brazil, 1980-1986. Rev Saude Publica. 1990;24:361-72.

12. Brasil. Ministério da Saúde. Datasus-sistema de informações de saúde. Available from: http:/ / www.datasus.gov.br. Accessed 12 December 2007.
13. Salomón OD, Sosa Estani S, Canini L, Córdoba Lanus E. Tegumentary leishmaniasis in area with epidemic levels of transmission, Salta, Argentina, 1998. Medicina (B Aires). 2001; 61(3):284-90.

14. Rotureau B, Joubert M, Clyti E, Djossou F, Carme B. Leishmaniasis among gold miners, French Guiana. Emerg Infect Dis. 2006;12(7) 1169-70.

15. Mestre GLC, Fontes CJF. The spread of visceral leishmaniasis epidemic in State of Mato Grosso, 1998-2005. Rev Soc Bras Med Trop. 2007;40(1):42-8.

16. Sherlock IA. Ecological interactions of visceral leishmaniasis in the State of Bahia. Mem Inst Oswaldo Cruz. 1996;91(6):671-83.

17. Sundar S, Jha TK, Thakur CP, Engel J, Sindermann $\mathrm{H}$, Fischer $\mathrm{C}$, et al. Oral miltefosine for Indian visceral leishmaniasis. N Engl J Med. 2002;347:1739-46.

Manuscript received on 16 April 2008. Revised version accepted for publication on 24 March 2009.

RESUMEN Objetivos. La leishmaniasis visceral (LV) es endémica en Brasil y suele ocurrir en forma epidémica en el estado de Ceará. Se han realizado pocos estudios epidemiológicos sobre LV en ese estado. El objetivo de este estudio es establecer el patrón epidemiológico de LV en la ciudad de Fortaleza y mostrar cómo ha ocurrido la urbanización de esta enfermedad en los últimos años.

Métodos. Los datos se obtuvieron del Departamento Estatal de Salud de Fortaleza, Ceará, y abarcaron todos los casos de LV registrados en esa ciudad entre enero de 2001 y diciembre de 2006.

Resultados. Se observó un marcado incremento y una elevada incidencia de LV en las áreas urbanas. Los niños y jóvenes fueron los grupos más afectados.

Conclusión. La ocurrencia de epidemias de LV en la región debe convencer a las autoridades para que adopten políticas más apropiadas para el control de esta enfermedad.

Palabras clave Leishmaniasis visceral; epidemiología; zonas urbanas; Brasil. 